\title{
Corymbia phloem phenolics, tannins and terpenoids: interactions with a cerambycid borer
}

\author{
R. Andrew Hayes $\cdot$ Andrew M. Piggott • \\ Timothy E. Smith $\cdot$ Helen F. Nahrung
}

Received: 17 December 2013/ Accepted: 21 February 2014

(C) Her Majesty the Queen in Right of Australia, as represented by the State of Queensland

acting through the Department of Agriculture, Fisheries and Forestry 2014

\begin{abstract}
Plant secondary chemistry mediates the ability of herbivores to locate, accept and survive on potential host plants. We examined the relationship between attack by the cerambycid beetle Phoracantha solida and the chemistry of the secondary phloem (inner bark) of two differentially attacked plantation forestry taxa, Corymbia variegata and its hybrid with $C$. torelliana. We hypothesised that this differential rate of attack may have to do with differences in secondary chemistry between the taxa. We found differences in the bark chemistry of the taxa, both with respect to phenolic compounds and terpenoids. We could detect no difference between bored and non-bored $C$. variegata trees (the less preferred, but co-evolved host). Hybrid trees were
\end{abstract}

Handling Editor: Kerstin Reifenrath.

R. A. Hayes $(\bowtie) \cdot$ T. E. Smith · H. F. Nahrung

Horticulture and Forestry Science, Agri-Science Queensland, Department of Agriculture, Fisheries and Forestry, Ecosciences Precinct, GPO Box 267, Brisbane, QLD 4001, Australia

e-mail: andrew.hayes@daff.qld.gov.au

R. A. Hayes - T. E. Smith - H. F. Nahrung

Forest Industries Research Centre, University of the Sunshine

Coast, Sippy Downs, QLD 4558, Australia

\section{A. M. Piggott}

Institute for Molecular Bioscience, The University

of Queensland, St Lucia, QLD 4072, Australia

A. M. Piggott

Department of Chemistry \& Biomolecular Sciences,

Macquarie University, North Ryde, NSW 2109, Australia

H. F. Nahrung

Faculty of Science, Health, Education and Engineering, University of the Sunshine Coast, Sippy Downs, QLD 4558, Australia not different in levels of total polyphenols, flavanols or terpenes according to attack status, but acetone extracts were significantly different between bored and non-bored trees. We propose that variations in the bark chemistry explain the differential attack rate between $C$. variegata and the hybrid hosts.

Keywords Bark chemistry - Phoracantha solida . Eucalypt $\cdot$ GC-MS $\cdot$ HPLC $\cdot$ LC-MS

\section{Introduction}

Constitutive defences are a plant's "first line of defence" and include physical barriers such as thick bark and lignin (Franceschi et al. 2005) and chemical defences such as terpenes and phenolics (Hallgren et al. 2003). Inducible defences, on the other hand, are triggered by insect or pathogen invasion and include formation of necrotic tissue that confines the invader (Paine et al. 1988) and increased levels of chemicals, to deter establishment and further attack (e.g. Eyles et al. 2003). It is widely believed that the best explanation for intraspecific differences in host plant susceptibility to herbivory or pathogenic attack is variations in the chemistry of the host plant (Zangerl and Berenbaum 1993).

Eucalypts are some of the world's most important and widely planted forest species (Turnball 2000), with more than 19,609,670 ha planted globally (Iglesias-Trabado and Wilstermann 2008). Species of the three closely related eucalypt genera (Eucalyptus, Angophora and Corymbia) produce large amounts and a wide variety of plant secondary metabolites (PSMs), especially terpeneoids and phenolic esters (see Henery et al. 2008 and references 
within). Terpenoid compounds accumulate in glands distributed throughout the foliage and the bark (secondary phloem) of the plant (Carr and Carr 1969) and may function as repellents, attractants, feeding stimulants, etc., to herbivores (Paine et al. 2011). There is also a link between phenolic compounds (e.g. tannins) and herbivory (e.g. Bernays 1981). In general for cerambycids, attractants tend to be monoterpenoids and phenolic esters, while oviposition stimulants are monoterpenoids and flavonoids (Allison et al. 2004).

Corymbia (Eucalyptus) torelliana (F. Muell.) K.D. Hill \& L.A.S. Johnson (section Torellianae) (Parra-O et al. 2009) is a rainforest tree whose endemic range occupies latitudes around $15.75-19^{\circ} \mathrm{S}$ (Boland et al. 2006), and is known to hybridise with the spotted gums (section $\mathrm{Macu}$ latae) including $C$. variegata (F.Muell.) K.D. Hill \& L.A.S. Johnson (Parra-O et al. 2009). A hybrid between $C$. torelliana and $C$. variegata has been developed for commercial purposes (Lee 2007), and has become among the preferred plantation species in subtropical Queensland and New South Wales due to their significant advantages in growth, and tolerance to disease, insects, and frost (Lee 2007; Lee et al. 2009, 2010).

The eucalypt woodborers (Phoracantha Fabricius: Cerambycidae) attack eucalypts (Myrtaceae) including Eucalyptus and Corymbia (Duffy 1963). Although the beetle genus is native to Australia, most work has been conducted overseas where two species ( $P$. semipunctata and $P$. recurva) have become commercially important pests of eucalypt plantations (Paine et al. 2011). As with other cerambycid beetles, olfaction is an important part of the biology of this genus used for host location (Allison et al. 2004). In particular, $P$. semipunctata uses olfactory cues in host location in field trials and laboratory trials, and these volatiles are detected by the beetle electrophysiologically (Barata et al. 2002, 1992, 2000; Barata and Araújo 2001). Three species of Phorocantha are pests within eucalypt plantations in Australia, P. solida, P. mastersi and $P$. acanthocera (Elliott et al. 1998); of these species, $P$. solida has the broadest geographic range and is the most significant pest of the three in the sub-tropics (Wang 1995). The life cycle of $P$. solida is approximately 2 years; females oviposit single eggs or small batches on branch stubs or injuries of otherwise apparently healthy trees $\geq 10 \mathrm{~cm}$ diameter; larvae create large amounts of damage beneath the outer bark, boring into the sapwood several times, and then returning there to pupate (Wang 1995). C. variegata is a known host for the species (Griffiths et al. 2004), and $C$. torelliana $\times C$. variegata hybrids developed for plantation forestry have been shown to be more susceptible to longicorn beetles than pure $C$. variegata (Nahrung et al. 2014).

We examined the impact of attack by $P$. solida on the chemistry of the secondary phloem (inner bark) of
C. variegata and its hybrid with $C$. torelliana. We hypothesised that differences in attack rate by the borer on the two tree taxa would be as a result of differences in plant secondary chemistry. Samples from bored and non-bored trees were examined for terpenoids and phenolic com pounds (e.g. tannins), and differences between classes were determined. We propose that differences in the chemistry of the secondary phloem between taxa will affect the beetle's ability to find, accept, and/or survive on hosts. The implications of differences between taxa with respect to cues for host location and host defence are discussed.

\section{Materials and methods}

Phloem sample collection

Phloem samples were collected on 24 October 2011 from a 3.83 ha site at Binjour Plateau, Queensland $\left(25.522^{\circ} \mathrm{S}\right.$ $157.478^{\circ} \mathrm{E}$ ) planted in May 2005 with C. variegata (spotted gum) and its hybrid with $C$. torelliana on a snuffy red ferrosol soil, which had boron treatments applied at the time of planting. Samples were collected from representative bored and non-bored trees for each taxon from throughout the site, with 11 replicate samples from each taxon-borer status combination. A tree was defined as bored if any visible evidence existed of damage from one or more beetle borers; attacks on these trees occur predominantly in the lower $50 \mathrm{~cm}$ of the trunk (Nahrung et al. 2014). Samples comprised a cylindrical bark core (25.4 $\mathrm{mm}$ diameter) removed from the southwestern side of the trunk, about $30 \mathrm{~cm}$ from the base, using a hammer and wad punch, extracting all phloem to the cambium. Each core was stored separately in a labelled paper bag, stored cold during transit and frozen until analysis.

Analysis of total polyphenols and flavanols

Samples were ground individually with a coffee grinder (Braun). The soluble phenolic compounds were extracted twice from $50 \mathrm{mg}$ of dry wood powder in $2 \mathrm{~mL}$ of a methanol:water solution $(8: 2, \mathrm{v} / \mathrm{v})$. The mixture was sonicated for $30 \mathrm{~min}$ at $4{ }^{\circ} \mathrm{C}$. One $\mathrm{mL}$ of pooled supernatant was removed and dried under vacuum, and re-dissolved in methanol $(250 \mu \mathrm{L})$.

Total polyphenols were estimated by an adapted FolinCiocalteu method (Pizzo et al. 2011; Singleton and Rossi 1965). Phenolic extract $(20 \mu \mathrm{L})$ was diluted in $80 \mu \mathrm{L}$ of ultra-pure water, $500 \mu \mathrm{L}$ of Folin-Ciocalteu's phenol reagent $2 \mathrm{~N}$ (Sigma, diluted 10 times in ultra-pure water) and $400 \mu \mathrm{L}$ of a $75 \mathrm{~g} / \mathrm{L} \mathrm{Na} \mathrm{CO}_{3}$ solution, mixed and incubated for $5 \mathrm{~min}$ at $40{ }^{\circ} \mathrm{C}$. The absorbance at $735 \mathrm{~nm}$ was measured spectrophotometrically (Centra 202 double beam 
spectrophotometer, GBC) and the results were expressed in $\mathrm{mg}$ of gallic acid equivalent (GAE) per gram dry weight (mg GAE/g d.m.). Calibration was achieved with gallic acid (Sigma) aqueous solutions (0-20 $\mu \mathrm{g} / \mathrm{mL})$.

The quantification of flavanols was carried out by a colorimetric method using 4-dimethylaminocinnamaldehyde (DMACA-Sigma) (Pizzo et al. 2011; Treutter 1989). $50 \mu \mathrm{L}$ of phenolic extract, $930 \mu \mathrm{L}$ of methanol and $20 \mu \mathrm{L}$ of DMACA solution (100 mg DMACA in $10 \mathrm{~mL}$ of 1.5 $\mathrm{M}$ methanolic sulphuric acid) were mixed and incubated for $2 \mathrm{~h}$ at room temperature. The flavanol content was determined spectrophotometrically (Centra 202 double beam spectrophotometer, GBC) at $630 \mathrm{~nm}$ using a standard curve based on catechin (Sigma) $(0-15 \mu \mathrm{g} / \mathrm{mL})$ and expressed in $\mathrm{mg}$ of catechin equivalent (CE) per gram dry mass (mg CE/g d.m.).

Phenolic compound analysis (LC-MS)

Samples were ground individually with a coffee grinder (Braun), sub-samples of which (230-250 mg) were then extracted in $1.5 \mathrm{~mL}$ of $70 \%$ aqueous acetone for $48 \mathrm{~h}$ in darkness at $4{ }^{\circ} \mathrm{C}$ (after Eyles et al. 2003). Solvent was removed by air-drying at ambient temperature, followed by drying under a stream of $\mathrm{N}_{2}$ at $40{ }^{\circ} \mathrm{C}$ then under high vacuum. The extracts were re-dissolved in methanol to a concentration of $10 \mathrm{mg} / \mathrm{mL}$ and filtered through a $0.45 \mu \mathrm{m}$ PTFE filter.

High-performance liquid chromatography-electrospray ionization mass spectrometry (HPLC-ESIMS) was performed using an Agilent 1100-series chromatography system coupled to an Agilent 1100-series single quadrupole mass spectrometer. HPLC gradient conditions were as follows: $1 \mathrm{~mL} / \mathrm{min}$ gradient elution from $90 \% \mathrm{H}_{2} \mathrm{O} / \mathrm{MeCN}$ $(0.05 \% \mathrm{HCOOH})$ to $\mathrm{MeCN}(0.05 \% \mathrm{HCOOH})$ over $15 \mathrm{~min}$, followed by a $5 \mathrm{~min}$ flush with $\mathrm{MeCN}$ using an Agilent Zorbax SB-C $_{8}$ column $(150 \mathrm{~mm} \times 4.6 \mathrm{~mm}$; $5 \mu \mathrm{m})$. Peaks were quantified by calculating area under the chromatogram at $254 \mathrm{~nm}$.

High resolution HPLC-ESIMS was performed using a Dionex Ultimate 3000 chromatography system coupled to a Bruker micrOTOF mass spectrometer. Mass calibration was performed before each analysis using sodium formate clusters as an internal standard. HPLC gradient conditions were as follows: $0.25 \mathrm{~mL} / \mathrm{min}$ gradient elution from $90 \%$ $\mathrm{H}_{2} \mathrm{O} / \mathrm{MeCN}(0.025 \% \mathrm{HCOOH})$ to $\mathrm{MeCN}(0.025 \%$ $\mathrm{HCOOH}$ ) over $10 \mathrm{~min}$, followed by a $5 \mathrm{~min}$ flush with MeCN using a Phenomenex Gemini-NX $\mathrm{C}_{18}$ column $(150 \mathrm{~mm} \times 2.0 \mathrm{~mm} ; 3 \mu \mathrm{m})$.

Terpenoid analysis (GC-MS)

Further sub-samples of the ground bark samples (230-250 mg) were extracted in methanol (1 mL) for $48 \mathrm{~h}$ in the dark at $4{ }^{\circ} \mathrm{C}$ (after Cadahia et al. 1997; Eyles et al. 2003). Samples were then stored in the freezer until analysis.

Samples $(1 \mu \mathrm{L})$ were analysed using gas chromatography (GC) (Agilent 6890 Series) coupled to mass spectrometry (MS) (Agilent 5975) and fitted with a silica capillary column (Agilent, model HP5-MS, $30 \mathrm{~m} \times$ $250 \mu \mathrm{m}$ ID $\times 0.25 \mu \mathrm{m}$ film thickness). Data were acquired under the following GC conditions-inlet temperature: $250{ }^{\circ} \mathrm{C}$, carrier gas: helium at $51 \mathrm{~cm} / \mathrm{s}$, split ratio $13: 1$, transfer-line temperature: $280{ }^{\circ} \mathrm{C}$, initial temperature: $40{ }^{\circ} \mathrm{C}$, initial time: $2 \mathrm{~min}$, rate: $10^{\circ} \mathrm{C} / \mathrm{min}$, final temperature: $260{ }^{\circ} \mathrm{C}$, final time: $6 \mathrm{~min}$. The MS was held at $280{ }^{\circ} \mathrm{C}$ in the ion source with a scan rate of 4.45 scans/s.

Peaks present in blank methanol (control) samples were discarded from analysis in test samples. Tentative identities were assigned to peaks with respect to the National Institute of Standards and Technology (NIST) mass spectral library. Mass spectra of peaks from different samples with the same retention time were compared to ensure that the compounds were indeed the same.

\section{Statistical analysis}

Differences in mean total polyphenols (mg GAE/g d.m.) and flavanols (mg CE/g d.m.) were analysed by MannWhitney $U$ test for differences between taxa, and between bored status across all trees. In addition, differences in the bored status were analysed within each taxon separately.

The presence of peaks in the chromatograms, and their relative areas were analysed by non-parametric multivariate statistical methods [Bray-Curtis cluster analysis and multidimensional scaling (MDS) ordination] (Clarke 1993) to ascertain whether any differences could be detected between the samples. Since they represent relative differences between samples, the axes of an MDS plot are dimensionless.

To determine whether clusters of individual plants relating to the taxa investigated were significantly different from each other, an analysis of similarity (ANOSIM) was used. The ANOSIM tests are a range of Mantel-type permutations of randomization procedures, which make no distributional assumptions. These tests depend only upon rank similarities, and thus are appropriate for these type of data. We used a similarity percentages (SIMPER) analysis to ascertain the relative contribution of each of the components to assign the bark to the a priori determined groups and to assess similarity between individuals within each group. Further analysis by ANOSIM and SIMPER was performed to detect any differences between bark from trees that had or had not been attacked by the cerambycid beetle borer. Differences in mean abundance were analysed by Mann-Whitney $U$ test for compounds which were found 
to be important to distinguish these categories. The software used for the univariate analysis was GenStat (V 14.2.0.6286), while that used for the multivariate analysis was Primer 5 for Windows (V 5.2.9, Clarke and Gorley 2001). These analytical procedures have been used successfully in previous studies to analyse chromatographic data (e.g. Hayes et al. 2006; Nahrung et al. 2009).

\section{Results}

Analysis of total polyphenols and flavanols

We detected no difference between taxa with respect to total polyphenol levels (mg GAE/g d.m.) (Mann-Whitney:

Table 1 Mean $( \pm$ SEM) total polyphenol (gallic acid equivalents) and flavanol (catechin equivalents) content detected in Corymbia bark from the bored and non-bored trees of Corymbia variegata and Corymbia torelliana $\times$ Corymbia variegata

\begin{tabular}{lllr}
\hline Taxon & Status & mg GAE/g d.m. & mg CE/g d.m. \\
\hline C. variegata & Bored & $1.94 \pm 0.25$ & $0.316 \pm 0.077$ \\
& Non-bored & $1.97 \pm 0.27$ & $0.368 \pm 0.065$ \\
C. torelliana $\times$ C. & Bored & $1.62 \pm 0.17$ & $0.0918 \pm 0.026$ \\
variegata & Non-bored & $1.52 \pm 0.25$ & $0.120 \pm 0.035$ \\
\hline
\end{tabular}

Table 2 Retention times, molecular weight and tentative molecular formulae of those components detected in aqueous acetone extracts of Corymbia bark that were important in distinguishing between the taxa

\begin{tabular}{|c|c|c|c|c|c|c|}
\hline \multirow[t]{2}{*}{$\begin{array}{l}\text { Ret Time } \\
(\min )\end{array}$} & \multirow[t]{2}{*}{ MW } & \multirow[t]{2}{*}{$\begin{array}{l}\text { Molecular } \\
\text { formula }\end{array}$} & \multicolumn{2}{|c|}{ C. variegata } & \multicolumn{2}{|c|}{$\begin{array}{l}\text { C. torelliana } \times \\
\text { C. variegata }\end{array}$} \\
\hline & & & Bored & $\begin{array}{l}\text { Non- } \\
\text { bored }\end{array}$ & Bored & $\begin{array}{l}\text { Non- } \\
\text { bored }\end{array}$ \\
\hline 3.65 & 934 & $\mathrm{C}_{42} \mathrm{H}_{46} \mathrm{O}_{24}$ & $1 / 11$ & $0 / 11$ & $11 / 11$ & $8 / 11$ \\
\hline 3.73 & 362 & $\mathrm{C}_{21} \mathrm{H}_{14} \mathrm{O}_{6}$ & $10 / 11$ & $10 / 11$ & $0 / 11$ & $0 / 11$ \\
\hline 4.82 & 450 & $\mathrm{C}_{20} \mathrm{H}_{18} \mathrm{O}_{12}$ & $4 / 11$ & $6 / 11$ & $9 / 11$ & $10 / 11$ \\
\hline 5.02 & a & $\mathrm{a}$ & $9 / 11$ & $7 / 11$ & $4 / 11$ & $6 / 11$ \\
\hline 5.30 & $\begin{array}{l}434 \\
478\end{array}$ & $\begin{array}{l}\mathrm{C}_{21} \mathrm{H}_{22} \mathrm{O}_{10} \\
\mathrm{a}\end{array}$ & $11 / 11$ & $9 / 11$ & $5 / 11$ & $7 / 11$ \\
\hline 5.43 & $\begin{array}{l}492 \\
498\end{array}$ & $\begin{array}{l}\mathrm{a} \\
\mathrm{C}_{22} \mathrm{H}_{26} \mathrm{O}_{13}\end{array}$ & $7 / 11$ & $10 / 11$ & $7 / 11$ & $7 / 11$ \\
\hline 6.43 & 288 & $\mathrm{C}_{15} \mathrm{H}_{12} \mathrm{O}_{6}$ & $10 / 11$ & $11 / 11$ & $1 / 11$ & $1 / 11$ \\
\hline 6.63 & 434 & $\mathrm{C}_{21} \mathrm{H}_{22} \mathrm{O}_{10}$ & $7 / 11$ & $9 / 11$ & $4 / 11$ & $1 / 11$ \\
\hline 6.72 & 434 & $\mathrm{C}_{21} \mathrm{H}_{22} \mathrm{O}_{10}$ & $0 / 11$ & $4 / 11$ & $11 / 11$ & $11 / 11$ \\
\hline 6.80 & 344 & $\mathrm{C}_{17} \mathrm{H}_{12} \mathrm{O}_{8}$ & $8 / 11$ & $4 / 11$ & $10 / 11$ & $10 / 11$ \\
\hline 7.94 & $\begin{array}{l}344 \\
490\end{array}$ & $\begin{array}{l}\mathrm{C}_{17} \mathrm{H}_{12} \mathrm{O}_{8} \\
\mathrm{C}_{23} \mathrm{H}_{22} \mathrm{O}_{12}\end{array}$ & $10 / 11$ & $9 / 11$ & $11 / 11$ & $11 / 11$ \\
\hline
\end{tabular}

The number out of 11 replicates of each taxon in which the component was identified is also shown

${ }^{\text {a }}$ Compounds for which we were unable to determine a molecular weight/formula
$U_{41}=170, P=0.143$ ), and no difference between levels in bored and non-bored trees. This lack of difference by bored status was true whether we considered all trees, or each of the taxa separately (All data: Mann-Whitney: $U_{41}=212, P=0.656 ; C$. variegata: Mann-Whitney: $U_{21}=54, P=0.699$; Hybrid: Mann-Whitney: $U_{20}=49$, $P=0.705$ ) (Table 1). Total flavanol (mg CE/g d.m.) levels were significantly lower in hybrid trees when compared to the spotted gum (Mann-Whitney: $U=66, P<0.001$ ), but again there were no differences between bored and nonbored trees, whether we looked at all trees or taxa separately (All data: Mann-Whitney: $U_{41}=189, P=0.317$; $C$. variegata: Mann-Whitney: $U_{21}=49, \quad P=0.478$; Hybrid: Mann-Whitney: $U_{20}=46, P=0.557$ ) (Table 1).
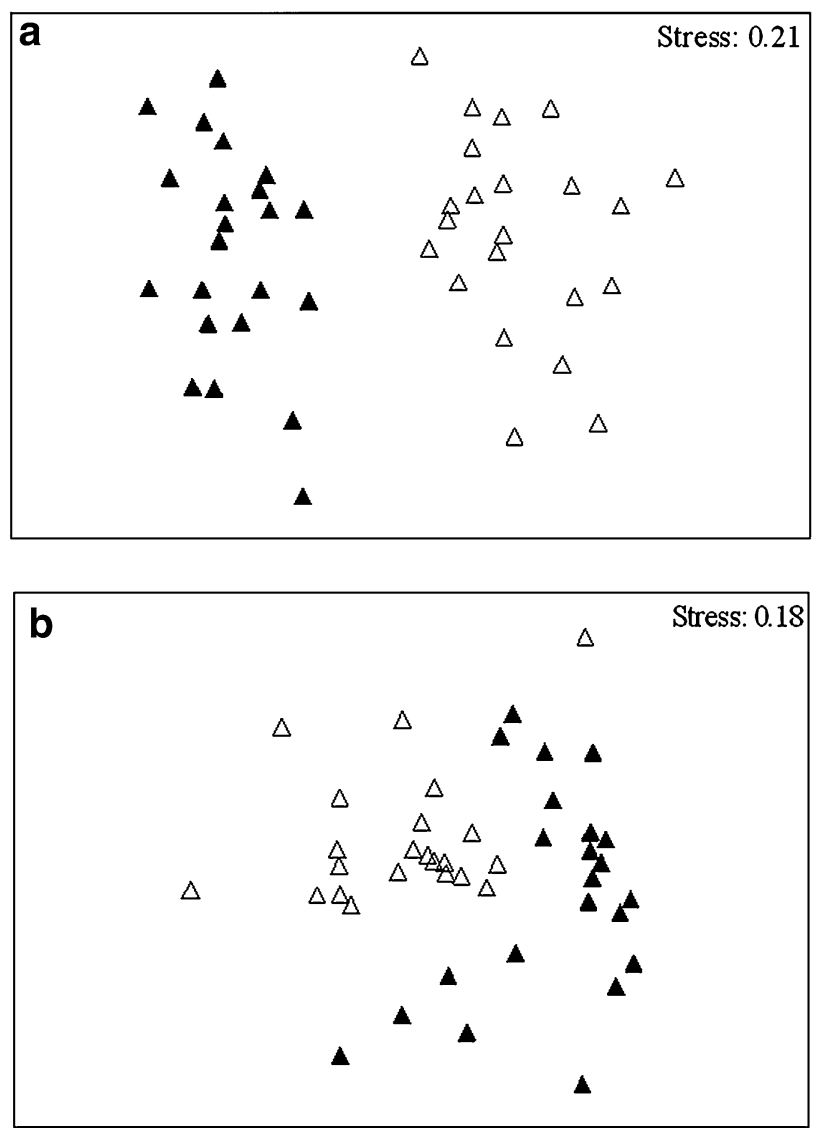

Fig. 1 a Phenolic compounds: two-dimensional MDS ordination of the 44 Corymbia bark extracts in aqueous acetone. The plot is based on fourth-root transformed abundances and a Bray-Curtis similarity matrix. Extracts from each taxon cluster separately. Symbols: Corymbia variegata (open triangle), Corymbia torelliana $\times$ Corymbia variegata (filled triangle). b Terpenoids: two-dimensional MDS ordination of the 44 Corymbia bark extracts in methanol. The plot is based on the fourth-root transformed abundances and a Bray-Curtis similarity matrix. Extracts from each taxon cluster separately. Symbols: Corymbia variegata (open triangle), hybrid-Corymbia torelliana $\times$ Corymbia variegata (filled triangle) 
Phenolic compound analysis (LC-MS)

Molecular weight and tentative molecular formulae were determined for some of the components detected in the aqueous acetone extracts of Corymbia bark (those shown to be important in distinguishing taxa, see below). All the listed molecular formulae correspond to known flavanol and flavanol glycosides (Table 2). For all samples, aqueous acetone extracts from the spotted gum and the hybrid were significantly different (ANOSIM: Global $R=0.79$, $P=0.001$ ) (Fig. 1a). The two taxa were also distinct within trees that were not bored (Global $R=0.723$, $P=0.001$ ) and those that were bored (ANOSIM: Global $R=0.846, P=0.001)$. SIMPER analysis shows the most important components contributing to these differences between the two taxa, while differences in the mean area under peaks in the chromatogram are also shown (Table 3).

To look for differences in chemicals extracted between bored and non-bored trees, we examined taxa separately (as taxa differed significantly). In neither taxon did we detect a difference between bored and non-bored trees $(C$. variegata: ANOSIM: Global $R=0.029, P=0.272$; Hybrid: ANOSIM: Global $R=0.017, P=0.33$ ).

Terpenoid analysis (GC-MS)

Retention times and tentative identities of components detected in methanol extracts of Corymbia bark are shown
(Table 4). As mentioned above, the methanol extracts from the two taxa were also significantly different, for all samples combined (ANOSIM: Global $R=0.405, P=0.001$ ), and within samples with borers (ANOSIM: Global $R=0.585, P=0.001$ ), and without borers (ANOSIM: Global $R=0.429, P=0.001$ (Fig. 1b). The most important components (as determined by the SIMPER analysis) for distinguishing the two taxa and differences between the mean area are shown (Table 5).

Because taxa differed, we tested for the effect of boring on them separately, and found no detectable differences between $C$. variegata that had or had not been bored (ANOSIM: Global $R=0.053, P=0.089$ ). However, $C$. torelliana $\times C$. variegata hybrids differed significantly according to the bored status (ANOSIM: Global $R=0.422, P=0.001$ ) (Fig. 2), with the most important components to distinguish the groups as determined by the SIMPER analysis, and differences between the mean area listed (Table 5).

\section{Discussion}

We examined the relationship between attack by $P$. solida and the chemistry of the secondary phloem (bark) of two important plantation forestry taxa in southeast Queensland, C. variegata and its hybrid with C. torelliana. Samples from the bored and non-bored trees were examined for

Table 3 Mean \pm SE percentage area under the peak for phenolic compounds (identified by retention time and molecular formula) used to distinguish between the taxa, sorted by increasing contribution to group dissimilarity

\begin{tabular}{|c|c|c|c|c|c|}
\hline $\begin{array}{l}\text { Ret Time } \\
(\mathrm{min})\end{array}$ & $\begin{array}{l}\text { Molecular } \\
\text { formula }\end{array}$ & $\begin{array}{l}\text { Mean } \% \text { area } C . \\
\text { variegata }\end{array}$ & $\begin{array}{l}\text { Mean } \% \text { area } C \text {. torelliana } \times C \text {. } \\
\text { variegata }\end{array}$ & $\begin{array}{l}\% \text { contribution to group } \\
\text { dissimilarity }\end{array}$ & Mann-Whitney $U$ \\
\hline 6.43 & $\mathrm{C}_{15} \mathrm{H}_{12} \mathrm{O}_{6}$ & $4.69 \pm 0.55$ & $0.10 \pm 0.09$ & 4.35 & $\begin{aligned} U_{42} & =24 \\
P & <0.001\end{aligned}$ \\
\hline 3.65 & $\mathrm{C}_{42} \mathrm{H}_{46} \mathrm{O}_{24}$ & $0.04 \pm 0.04$ & $7.3 \pm 1.3$ & 4.35 & $\begin{aligned} U_{42} & =36.5 \\
P & <0.001\end{aligned}$ \\
\hline 5.30 & $\mathrm{C}_{21} \mathrm{H}_{22} \mathrm{O}_{10}$ & $10.6 \pm 1.0$ & $1.76 \pm 0.44$ & 3.36 & $\begin{aligned} U_{42} & =24 \\
P & <0.001\end{aligned}$ \\
\hline 6.72 & $\mathrm{C}_{21} \mathrm{H}_{22} \mathrm{O}_{10}$ & $1.50 \pm 0.37$ & $1.50 \pm 0.35$ & 2.98 & n.s. \\
\hline 7.94 & $\begin{array}{l}\mathrm{C}_{17} \mathrm{H}_{12} \mathrm{O}_{8} \\
\mathrm{C}_{23} \mathrm{H}_{22} \mathrm{O}_{12}\end{array}$ & $0.39 \pm 0.07$ & $6.80 \pm 0.83$ & 2.89 & $\begin{aligned} U_{42} & =0 \\
P & <0.001\end{aligned}$ \\
\hline 3.73 & $\mathrm{C}_{21} \mathrm{H}_{14} \mathrm{O}_{6}$ & $0.85 \pm 0.19$ & 0 & 2.77 & $\begin{aligned} U_{42} & =22 \\
P & <0.001\end{aligned}$ \\
\hline 5.02 & $\mathrm{a}$ & $2.71 \pm 0.49$ & $2.00 \pm 0.82$ & 2.62 & $\begin{aligned} U_{42} & =157 \\
P & =0.039\end{aligned}$ \\
\hline 6.63 & $\mathrm{C}_{21} \mathrm{H}_{22} \mathrm{O}_{10}$ & $0.92 \pm 0.33$ & $0.08 \pm 0.04$ & 2.57 & n.s. \\
\hline 4.82 & $\mathrm{C}_{20} \mathrm{H}_{18} \mathrm{O}_{12}$ & $1.87 \pm 0.46$ & $1.81 \pm 0.24$ & 2.41 & n.s. \\
\hline 6.80 & $\mathrm{C}_{17} \mathrm{H}_{12} \mathrm{O}_{8}$ & $1.72 \pm 0.83$ & $3.40 \pm 0.44$ & 2.37 & $\begin{aligned} U_{42} & =126 \\
P & =0.006\end{aligned}$ \\
\hline 5.43 & $? \mathrm{C}_{22} \mathrm{H}_{26} \mathrm{O}_{13}$ & $2.93 \pm 0.43$ & $1.92 \pm 0.52$ & 2.19 & $\begin{aligned} U_{42} & =134 \\
P & =0.01\end{aligned}$ \\
\hline
\end{tabular}

${ }^{a}$ Compounds for which we were unable to determine a molecular weight/formula 
Table 4 Retention times and tentative identities of components detected in methanol extracts of Corymbia bark and the number out of 11 replicates of each taxon in which the component was identified

\begin{tabular}{|c|c|c|c|c|c|}
\hline \multirow[t]{2}{*}{ Ret Time (min) } & \multirow[t]{2}{*}{ Compound id } & \multicolumn{2}{|c|}{ C. variegata } & \multicolumn{2}{|c|}{ C. torelliana $\times$ C. variegata } \\
\hline & & Bored & Non-bored & Bored & Non-bored \\
\hline 3.12 & a & $0 / 11$ & $1 / 11$ & $0 / 11$ & $0 / 11$ \\
\hline 3.17 & a & $0 / 11$ & $1 / 11$ & $0 / 11$ & $1 / 11$ \\
\hline 3.81 & furfural & $11 / 11$ & $11 / 11$ & $11 / 11$ & $11 / 11$ \\
\hline 4.18 & a & $0 / 11$ & $0 / 11$ & $0 / 11$ & $1 / 11$ \\
\hline 4.61 & 4-methoxy-2-butanone & $10 / 11$ & $11 / 11$ & $11 / 11$ & $3 / 11$ \\
\hline 4.72 & a & $0 / 11$ & $0 / 11$ & $0 / 11$ & $3 / 11$ \\
\hline 5.50 & a & $0 / 11$ & $0 / 11$ & $0 / 11$ & $3 / 11$ \\
\hline 5.54 & $\beta$-methoxy-2-furanethanol & $1 / 11$ & $1 / 11$ & $4 / 11$ & $3 / 11$ \\
\hline 5.88 & $\beta$-pinene & $11 / 11$ & $11 / 11$ & $11 / 11$ & $11 / 11$ \\
\hline 5.92 & a & $1 / 11$ & $0 / 11$ & $0 / 11$ & $0 / 11$ \\
\hline 6.42 & a & $0 / 11$ & $2 / 11$ & $0 / 11$ & $2 / 11$ \\
\hline 6.52 & 1-isopropyl-2-propylhydrazine & $1 / 11$ & $1 / 11$ & $2 / 11$ & $4 / 11$ \\
\hline 7.25 & ethylacethydroxamate & $8 / 11$ & $11 / 11$ & $3 / 11$ & $5 / 11$ \\
\hline 7.28 & a & $0 / 11$ & $0 / 11$ & $0 / 11$ & $1 / 11$ \\
\hline 7.59 & furyl, hydroxymethylketone & $1 / 11$ & $0 / 11$ & $10 / 11$ & $5 / 11$ \\
\hline 8.60 & 2,3-dihydro-3,5-dihydroxy-6-methyl-4H-pyran-4-one & $11 / 11$ & $11 / 11$ & $11 / 11$ & $11 / 11$ \\
\hline 8.71 & a & $0 / 11$ & $0 / 11$ & $2 / 11$ & $2 / 11$ \\
\hline 9.03 & 1-methyl-2(1H)-pyridinone & $10 / 11$ & $11 / 11$ & $2 / 11$ & $11 / 11$ \\
\hline 9.13 & 4-methyl-3-oxovaleric acid, ethyl ester & $0 / 11$ & $0 / 11$ & $11 / 11$ & $4 / 11$ \\
\hline 9.63 & 1,1,2-trimethoxyethane & $2 / 11$ & $7 / 11$ & $8 / 11$ & $8 / 11$ \\
\hline 9.95 & 5-hydroxymethylfurfural (HMF) & $11 / 11$ & $11 / 11$ & $11 / 11$ & $11 / 11$ \\
\hline 10.10 & a & $2 / 11$ & $1 / 11$ & $3 / 11$ & $1 / 11$ \\
\hline 10.20 & a & $1 / 11$ & $0 / 11$ & $1 / 11$ & $0 / 11$ \\
\hline 11.15 & a & $1 / 11$ & $0 / 11$ & $0 / 11$ & $0 / 11$ \\
\hline 17.84 & 14-methylpentadecanoic acid, methyl ester & $7 / 11$ & $7 / 11$ & $0 / 11$ & $1 / 11$ \\
\hline 17.84 & a & $0 / 11$ & $0 / 11$ & $1 / 11$ & $0 / 11$ \\
\hline 18.24 & $n$-hexadecanoic acid & $9 / 11$ & $10 / 11$ & $11 / 11$ & $11 / 11$ \\
\hline 18.62 & a & $0 / 11$ & $1 / 11$ & $3 / 11$ & $2 / 11$ \\
\hline 19.00 & a & $1 / 11$ & $1 / 11$ & $0 / 11$ & $0 / 11$ \\
\hline 19.35 & a & $1 / 11$ & $0 / 11$ & $0 / 11$ & $0 / 11$ \\
\hline 19.45 & 8,11-octadecadienoic acid, methyl ester & $8 / 11$ & $6 / 11$ & $3 / 11$ & $2 / 11$ \\
\hline 19.52 & linolenic acid, methyl ester & $5 / 11$ & $3 / 11$ & $0 / 11$ & $2 / 11$ \\
\hline 19.86 & linoleic acid & $1 / 11$ & $0 / 11$ & $2 / 11$ & $11 / 11$ \\
\hline 20.12 & $\mathrm{a}$ & $0 / 11$ & $0 / 11$ & $1 / 11$ & $0 / 11$ \\
\hline 25.00 & $\beta$-sitosterol & $10 / 11$ & $11 / 11$ & $10 / 11$ & $11 / 11$ \\
\hline
\end{tabular}

${ }^{a}$ Compounds for which we were unable to determine an identity

terpenoids and phenolic compounds (e.g. flavanols, tannins), and differences between classes determined.

We found differences in the secondary phloem chemistry of the taxa, both with respect to phenolic compounds and terpenoids. These differences concur with those reported previously for differences in foliar chemistry between parent and hybrid taxa (Hayes et al. 2013). There are also differences in their susceptibility to attack by $P$. solida with nine times more attacks on the hybrid than $C$. variegata (Nahrung et al. 2014). Some aspect of this chemical variation may affect this differential attack rate.

It may be that the lower susceptibility is a result of greater chemical defences in the co-evolved host (C. variegata) than in the "naïve" host $(C$. torelliana $\times$ $C$. variegata). Alternatively, the observed differences in terpenoids between the taxa (Fig. 1b) may explain this variation. Terpenoid differences are associated with variation in host location by cerambycid beetles (Allison et al. 


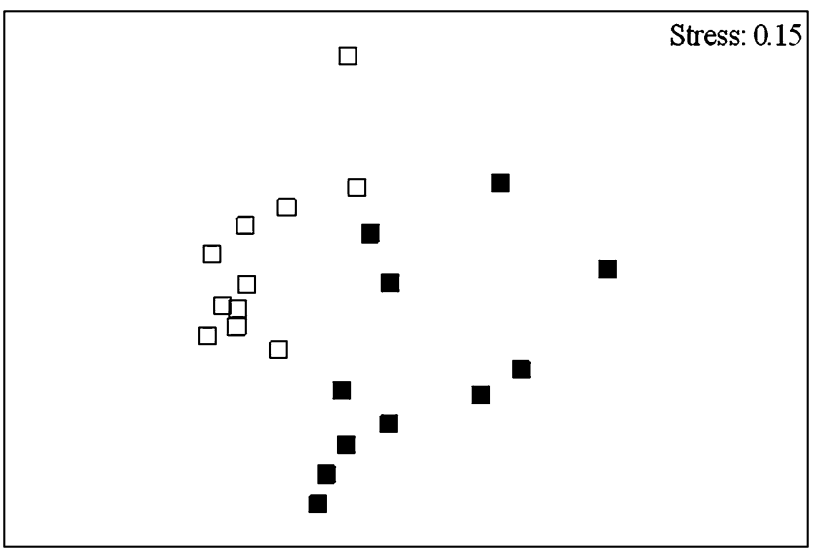

Fig. 2 Terpenoid: two-dimensional MDS ordination of the 22 methanol bark extracts of $C$. torelliana $\times C$. variegata. The plot is based on the fourth-root transformed abundances and a Bray-Curtis similarity matrix. Extracts from bored (open square) and non-bored (filled square) trees cluster separately
2004), and it may be that the hybrid trees are easier for the beetles to recognise as a suitable oviposition site [both parental taxa are sympatric to the beetle (Wang 1995)]. Hybrid trees at this study site appeared more stressed than C. variegata (Nahrung et al. 2014), and stress is well known to lead to differences in chemical profiles of trees (e.g. Copolovici and Niinemets 2010; Niinemets 2010; Steindel et al. 2005).

There was no chemical difference detected between bored and non-bored C. variegata trees. This was true whether we compared total polyphenols, flavanols, acetone or methanolic extracts. Interestingly, in the case of the hybrid, although there was no chemical difference observed with the total polyphenols, flavanols and acetone extracts, bored and non-bored hybrids were significantly chemically distinct in the methanol extracts. Do the variations in these predominantly volatile components explain

Table 5 Mean \pm SE percentage area under the peak for compounds (identified by retention time) used to distinguish between (a) the taxa and (b) the C. torelliana $\times$ C. variegata hybrids that had or had not been bored

(a)

\begin{tabular}{|c|c|c|c|c|c|}
\hline Ret Time (min) & Compound i.d. & $\begin{array}{l}\text { Mean } \% \text { area } \\
\text { C. variegata }\end{array}$ & $\begin{array}{l}\text { Mean } \% \text { area } \\
\text { C. torelliana } \times \\
\text { C. variegata }\end{array}$ & $\begin{array}{l}\% \text { contribution to } \\
\text { group dissimilarity }\end{array}$ & Mann-Whitney $U$ \\
\hline 7.25 & ethylacethydroxamate & $3.19 \pm 0.71$ & $1.03 \pm 0.39$ & 8.60 & $U_{42}=115, P=0.002$ \\
\hline 9.13 & 4-methyl-3-oxovaleric acid, ethyl ester & 0 & $1.16 \pm 0.19$ & 7.37 & $U_{42}=77, P<0.001$ \\
\hline 7.59 & furyl, hydroxymethylketone & $0.04 \pm 0.04$ & $0.81 \pm 0.15$ & 6.55 & $U_{42}=82.5, P<0.001$ \\
\hline 19.45 & 8,11-octadecadienoic acid, methyl ester & $1.40 \pm 0.47$ & $0.42 \pm 0.19$ & 6.46 & $U_{42}=149, P=0.015$ \\
\hline 17.84 & 14-methylpentadecanoic acid, methyl ester & $0.93 \pm 0.28$ & $0.07 \pm 0.07$ & 6.07 & $U_{42}=101, P<0.001$ \\
\hline 9.03 & 1-methyl-2(1H)-pyridinone & $2.07 \pm 0.27$ & $1.10 \pm 0.24$ & 5.79 & $U_{42}=134.5, P=0.01$ \\
\hline 9.63 & 1,1,2-trimethoxy ethane & $0.64 \pm 0.19$ & $0.80 \pm 0.15$ & 5.79 & n. s. \\
\hline 4.61 & 4-methoxy-2-butanone & $3.31 \pm 0.68$ & $1.25 \pm 0.48$ & 5.61 & $U_{42}=98, P<0.001$ \\
\hline 19.86 & linoleic acid & $0.03 \pm 0.03$ & $0.61 \pm 0.12$ & 5.49 & $U_{42}=103.5, P<0.001$ \\
\hline 25.00 & $\beta$-sitosterol & $26.8 \pm 2.5$ & $26.3 \pm 2.5$ & 3.99 & n. s. \\
\hline 19.52 & linolenic acid, methyl ester & $0.62 \pm 0.27$ & $0.15 \pm 0.10$ & 3.88 & n. s. \\
\hline
\end{tabular}

(b)

\begin{tabular}{|c|c|c|c|c|c|}
\hline Ret Time (min) & Compound i.d. & $\begin{array}{l}\text { Mean } \% \text { area } \\
\text { bored }\end{array}$ & $\begin{array}{l}\text { Mean \% area } \\
\text { non-bored }\end{array}$ & $\begin{array}{l}\% \text { contribution to } \\
\text { group dissimilarity }\end{array}$ & Mann-Whitney $U$ \\
\hline 9.03 & 1-methyl-2(1H)-pyridinone & $0.41 \pm 0.28$ & $1.80 \pm 0.25$ & 9.73 & $U_{20}=15, P=0.002$ \\
\hline 19.86 & linoleic acid & $0.15 \pm 0.10$ & $1.08 \pm 0.10$ & 8.67 & $U_{20}=5, P<0.001$ \\
\hline 9.13 & 4-methyl-3-oxovaleric acid, ethyl ester & $1.65 \pm 0.12$ & $0.68 \pm 0.29$ & 8.06 & $U_{20}=28, P=0.034$ \\
\hline 4.61 & 4-methoxy-2-butanone & $1.25 \pm 0.16$ & $2.81 \pm 0.97$ & 7.55 & $U_{20}=23, P=0.013$ \\
\hline 7.59 & furyl, hydroxymethylketone & $1.11 \pm 0.19$ & $0.50 \pm 0.19$ & 6.24 & n. s. \\
\hline 7.25 & ethylacethydroxamate & $0.30 \pm 0.20$ & $1.77 \pm 0.70$ & 6.22 & n. s. \\
\hline 9.63 & 1,1,2-trimethoxy ethane & $0.76 \pm 0.20$ & $0.84 \pm 0.24$ & 5.00 & n. s. \\
\hline 5.54 & $\beta$-methoxy-(S)-2-furanethanol & $0.41 \pm 0.19$ & $0.55 \pm 0.29$ & 4.90 & n. s. \\
\hline 5.88 & $\beta$-pinene & $1.69 \pm 0.36$ & $3.9 \pm 1.3$ & 4.08 & n. s. \\
\hline 25.00 & $\beta$-sitosterol & $25.5 \pm 3.8$ & $27.1 \pm 3.2$ & 3.96 & n. s. \\
\hline 6.52 & 1-isopropyl-2-propylhydrazine & $0.09 \pm 0.06$ & $0.41 \pm 0.19$ & 3.95 & n. s. \\
\hline
\end{tabular}


the ability of the beetle to find the hybrid hosts? The presence of olfactory sensilla on the ovipositor of the congeneric $P$. recurva suggests that olfactory cues from bark are important in oviposition in this species (Faucheux 2012).

The bored and non-bored status of the trees used in our study arises through a combination of female oviposition choice and larval survival, and it is difficult to differentiate these effects. However, the differences in attack rate and secondary chemistry between taxa, and the general similarity in profiles between bored and non-bored trees within taxa suggest that, if they are contributing to the distribution of beetles, it is more likely due to differences in host location and acceptance than to larval performance. Only one compound (4-methyl-3-oxovaleric acid, ethyl ester) was present at a higher level in bored compared with nonbored hybrid hosts, and while this may represent an induced response (see Eyles et al. 2010), we are unable to distinguish between an induced response and an underlying constitutive difference between the trees.

The other three compounds that differed between bored and non-bored hybrids were higher in the latter, and likely represent constitutive differences between the taxa. Indeed the compound that contributes most to dissimilarity between the bored and non-bored groups is 1-methyl$2(1 \mathrm{H})$-pyridinone. This compound is a known entomotoxin, and has been shown to have very high levels of mortality in screwworm larvae feeding on it at even low concentrations (Oliver and Crystal 1972). It is possible that even if there is no difference in oviposition preference between hybrid trees, levels of this compound affect larval survival, and thus detectable damage in non-bored trees.

Overall, there was no difference between bored and nonbored C. variegata, although upon examining each compound individually we found significantly higher levels of $\beta$-pinene in bored rather than non-bored (Mann-Whitney: $U_{20}=24.0, P=0.016$ ), while levels of this monoterpene were not significantly different in the other combinations of taxon and status. This compound is electrophysiologically active for the congeneric beetle $P$. semipunctata (Barata et al. 2000, 2002).

Factors other than the secondary metabolites may also influence the patterns of attack we report here. For example, bark moisture content has previously been found to be important in resistance of eucalypts to borer attack (Hanks et al. 1991). In addition, reduction in larval performance of $P$. semipunctata in two Corymbia species (C. maculata and C. citriodora) was recently attributed to sapwood reaction and kino (resin) production (Haddan et al. 2010). Farr et al. (2000) reported a significant relationship between kino and Phorocantha attack in Western Australia, and Carnegie et al. (2008) described kino bleeding as characteristic in early stages of $P$. solida attack, and its role, therefore, warrants further investigation. Nevertheless, we propose that variations in the chemistry of the secondary phloem (inner bark) of these trees explain, at least in part, the differential attack rate or larval survival between $C$. variegata and the hybrid hosts by the important boring pest $P$. solida.

Acknowledgments We sincerely thank Michael O'Loughlin, Fred Oudyn (DSITIA) and Lesley Francis (DAFF) for access to equipment and advice and assistance with spectrophotometric analyses and to A/Prof David Lee (USC/DAFF) for tree germplasm. Thanks to Forest Plantations Qld for establishment and access to the field site. This work was partially funded by Plantation Hardwoods Research and Development Fund, Elders Forestry and HQPlantations (formerly FPQ).

\section{References}

Allison JD, Borden JH, Seybold SJ (2004) A review of the chemical ecology of the Cerambycidae (Coleoptera). Chemoecol 14:123-150

Barata EN, Araújo J (2001) Olfactory orientation responses of the eucalyptus woodborer, Phoracantha semipunctata, to host plant in a wind tunnel. Physiol Entomol 26:26-37

Barata EN, Fonseca PJ, Mateus E, Araujo J (1992) Host-finding by Phoracantha semipunctata: host volatiles, electroantennogram recordings and baited field traps. In: Menken SBJ, Visser JH, Harrewijn P (eds) Proceedings of the 8th International Symposium on Insect-Plant Relationships. Springer, Netherlands, pp 133-135

Barata EN, Pickett JA, Wadhams LJ, Woodcock CM, Mustaparta H (2000) Identification of host and nonhost semiochemicals of eucalyptus woodborer Phoracantha semipunctata by gas chromatography-electroantennography. J Chem Ecol 26:1877-1895

Barata E, Mustaparta H, Pickett J, Wadhams L, Araujo J (2002) Encoding of host and non-host plant odours by receptor neurones in the eucalyptus woodborer, Phoracantha semipunctata (Coleoptera: Cerambycidae). J Comp Physiol A 188:121-133

Bernays EA (1981) Plant tannins and insect herbivores: an appraisal. Ecol Entomol 6:353-360

Boland DJ, Brooker MH, Chippendale GM, Hall N, Hyland BPM, Johnston RD, Kleinig DA, Turner JD (2006) Forest trees of Australia. CSIRO Publishing, Melbourne

Cadahia E, Conde F, Fernandez de Simon B, Garcia-Vallejo MC (1997) Tannin composition of Eucalyptus camaldulensis, E. globulus and E. rudis. Part II Bark Holzforsch 51:125-129

Carnegie AJ, Lawson SA, Smith TE, Pegg GS, Stone C, McDonald JM (2008) Healthy hardwoods: a field guide to pests, diseases and nutritional disorders in subtropical hardwoods. Forest and Wood Products Australia, Melbourne

Carr SGM, Carr DJ (1969) Oil glands and ducts in Eucalyptus L'Hérit. I the phloem and the pith. Aust J Bot 17:471-513

Clarke KR (1993) Non-parametric multivariate analysis of changes in community structure. Aust J Ecol 18:117-143

Clarke KR, Gorley RN (2001) PRIMER v5: User Manual/Tutorial. PRIMER-E, Plymouth

Copolovici L, Niinemets U (2010) Flooding induced emissions of volatile signalling compounds in three tree species with differing waterlogging tolerance. Plant Cell Environ 33:1582-1594

Duffy EAJ (1963) A monograph of the immature stages of Australasian timber beetles (Cerambycidae). British Museum (Natural History), London 
Elliott HJ, Ohmart CP, Wylie FR (1998) Insect pests of Australian forests. Inkata Press, Melbourne

Eyles A, Davies NW, Yuan ZQ, Mohammed C (2003) Host responses to natural infection by Cytonaema sp. in the aerial bark of Eucalyptus globulus. For Path 33:317-331

Eyles A, Bonello P, Ganley R, Mohammed C (2010) Induced resistance to pests and pathogens in trees. New Phytol 185:893-908

Farr JD, Dick SG, Williams MR, Wheeler IB (2000) Incidence of the bullseye borer (Phoracantha acanthocera (Macleay), Cerambycidae) in 20-35 year old regrowth karri in the south west of Western Australia. Aust For 63:107-123

Faucheux MJ (2012) Ovipositor sensilla of the yellow longicorn beetle Phoracantha recurva Newman, 1840 (Coleoptera: Cerambycidae). Bull Inst Sci Rabat 34:11-18

Franceschi VR, Krokene P, Christiansen E, Krekling T (2005) Anatomical and chemical defenses of conifer bark against bark beetles and other pests. New Phytol 167:353-375

Griffiths M, Wylie R, Lawson S, Pegg G, McDonald J (2004) Known or potential threats from pests and diseases to prospective tree species for high value timber plantings in northern Australia. In: Bevege DI, Bristow M, Nikles DG, Skelton DJ (eds) Prospects for high-value hardwood timber plantations in the 'dry' tropics of northern Australia Proceedings of a Workshop held 19-21 October, 2004. Private Forestry North Queensland Association Inc, Mareeba

Haddan M, Sauvard D, Lieutier F (2010) Tree factors in relation to success of artifical introductions of Phoracantha recurva larvae in various Eucalyptus species in Morocco. Redia 93:19-30

Hallgren P, Ikonen A, Hjältén J, Roininen H (2003) Inheritance patterns of phenolics in F1, F2, and back-cross hybrids of willows: implications for herbivore responses to hybrid plants. J Chem Ecol 29:1143-1158

Hanks LM, Paine TD, Millar JG (1991) Mechanisms of resistance in Eucalyptus against larvae of the eucalyptus longhorned borer (Coleoptera: Cerambycidae). Environ Entomol 20:1583-1588

Hayes RA, Morelli TL, Wright PC (2006) Volatile components of lemur scent secretions vary throughout the year. Am J Primatol 68:1202-1207

Hayes RA, Nahrung HF, Lee DJ (2013) Consequences of Corymbia (Myrtaceae) hybridisation on leaf-oil profiles. Aust $\mathrm{J}$ Bot 61:52-59

Henery ML, Henson M, Wallis IR, Stone C, Foley WJ (2008) Predicting crown damage to Eucalyptus grandis by Paropsis atomaria with direct and indirect measures of leaf composition. For Ecol Manage 255:3642-3651

Iglesias-Trabado G, Wilstermann D (2008) Eucalyptus universalis. Global cultivated eucalypt forests map 2008. Version 1.0.1.: GIT Forestry Consulting's EUCALYPTOLOGICS

Lee DJ (2007) Achievements in forest tree genetic improvement in Australia and New Zealand 2: development of Corymbia species and hybrids for plantations in eastern Australia. Aust For 70:11-16
Lee DJ, Huth JR, Brawner JT, Dickinson GR (2009) Comparative performance of Corymbia hybrids and parental species in subtropical Queensland and implications for breeding and deployment. Silv Genet 58:205-212

Lee DJ, Huth JR, Osborne DO, Hogg BW (2010) Selecting hardwood varieties for fibre production in Queensland's subtropics. Aust For 73:106

Nahrung HF, Waugh R, Hayes RA (2009) Corymbia species and hybrids: chemical and physical foliar attributes and implications for herbivory. J Chem Ecol 35:1043-1053

Nahrung HF, Smith TE, Wiegand AN, Lawson SA, Debuse VJ (2014) Host tree influences on longicorn beetle (Coleoptera: Cerambycidae) attack in subtropical Corymbia (Myrtales: Myrtaceae). Environ Entomol 43:37-46. doi:10.1603/EN13133

Niinemets U (2010) Responses of forest trees to single and multiple environmental stresses from seedlings to mature plants: past stress history, stress interactions, tolerance and acclimation. For Ecol Manage 260:1623-1639

Oliver JE, Crystal MM (1972) Chemosterilants against screwworm flies. J Econ Entomol 65:303-306

Paine TD, Stephen FM, Cates RG (1988) Phenology of an induced response in loblolly pine following inoculation of fungi associated with the southern pine beetle. Can J For Res 18:1556-1562

Paine TD, Steinbauer MJ, Lawson SA (2011) Native and exotic pests of Eucalyptus: a worldwide perspective. Ann Rev Entomol $56: 181-201$

Parra-O C, Bayly MJ, Drinnan A, Udovicic F, Ladiges PY (2009) Phylogeny, major clades and infrageneric classification of Corymbia (Myrtaceae), based on nuclear ribisomal DNA and morphology. Aust Syst Bot 22:384-399

Pizzo B, Pometti C, Charpentier J-P, Boizot N, Saidman B (2011) Relationships involving several types of extractives of five native Argentine wood species of genera Prosopis and Acacia. Ind Crops Prod 34:851-859

Singleton V, Rossi JJ (1965) Colorimetry of total phenolics with phosphomolybdic-phosphotungstic acid reagents. Am J Enol Vitic 16:144-158

Steindel F, Beauchamp J, Hansel A, Kesselmeier J, Kleist E, Kuhn U, Wisthaler A, Wildt J (2005) Stress induced VOC emissions from mildew infested oak. Geophys Res Abs 7: EGU05-A-03010

Treutter D (1989) Chemical reaction detection of catechins and proanthocyanidins with 4-dimethylaminocinnamaldehyde. J Chromatog A 467:185-193

Turnball JW (2000) Economic and social importance of eucalypts. In: Keane PJ, Kile GA, Podger FD, Brown BN (eds) Diseases and pathogens of eucalypts. CSIRO Publishing, Melbourne, pp 1-9

Wang Q (1995) A taxonomic revision of the Australian genus Phoracantha Newman (Coleotpera: Chrysomelidae). Invert Taxon 9:865-958

Zangerl AR, Berenbaum MR (1993) Plant chemistry, insect adaptations to plant chemistry, and host plant utilization patterns. Ecol $74: 47-54$ 